\title{
Aging Education: A Worldwide Imperative
}

\author{
Sandra L. McGuire \\ The University of Tennessee, Knoxville, TN, USA \\ Email: smcguire@utk.edu
}

How to cite this paper: McGuire, S. L. (2017). Aging Education: A Worldwide Imperative. Creative Education, 8, 1878-1891. https://doi.org/10.4236/ce.2017.812128

Received: August 7, 2017

Accepted: September 24, 2017

Published: September 27, 2017

Copyright $\odot 2017$ by author and Scientific Research Publishing Inc. This work is licensed under the Creative Commons Attribution International License (CC BY 4.0).

http://creativecommons.org/licenses/by/4.0/ (c) (†) Open Access

\begin{abstract}
Life expectancy is increasing worldwide. Unfortunately, people are generally not prepared for this long life ahead and have ageist attitudes that inhibit maximizing the "longevity dividend" they have been given. Aging education can prepare people for life's later years and combat ageism. It can reimage aging as a time of continued growth, development and fulfillment. Unfortunately, aging education is not a common occurrence. This education needs to begin with children and continue throughout life. This article discusses why we need to teach about aging and aging education content, suggests a conceptual framework for aging education, and presents aging education resources. The concept of ageism is discussed and suggestions for combating ageism are proposed.
\end{abstract}

\section{Keywords}

Aging, Aging Education, Ageism, Attitudes about Aging, Children's

Literature and Aging, Intergenerational Connections

\section{Aging Education: A Worldwide Imperative}

Worldwide, aging is a process in which everyone is already involved. It is a lifelong experience not just a later life occurrence. Changing world demographics illustrate that people are living longer. Among the world's young people, survival to age 80 is expected to be commonplace (United Nations, 2015). This new found "longevity dividend" needs to be maximized and enjoyed. Increased longevity and worldwide aging are constantly in the public view, yet preparing people for this long life has received little attention. People need to be prepared to live a long life in an aging world (Couper \& Pratt, 1999; Crawford, 2015; Crawford, 2000). Aging education can prepare people for the long life ahead of them, promote "aging with optimism", and combat ageism. 


\section{Ageism}

Dr. Robert Butler, a renowned gerontologist and the first director of the National Institute on Aging in the United States, defined ageism as stereotyping and discrimination against people because they are old (Butler, 1969; Butler \& Lewis, 1973). Ageism has been described as the ultimate prejudice and the cruelest form of rejection (Palmore, 2001; 2003). Like other "isms" ageism devalues and influences the behaviors of its victims (Butler, 1995) and influences the behaviors of others toward older people. Unlike other "isms" that target specific groups, ageism has the potential to target everyone. Ageism is a worldwide occurrence (Palmore, 2004). Ageist attitudes inhibit understanding that there is potential for activity, happiness, wellness, and fulfillment throughout life (Pratt, 1983). Ageism exists in many different forms. It has become so commonplace that it may actually be an unintentional bias, an unconscious force that is not even recognized when it occurs (Levy, 2003; Sweetland, Volmert, \& O’Neil, 2017). More than 100 forms of ageism have been identified in the Encyclopedia of Ageism (Palmore, Branch, \& Harris, 2005).

The Revera Report on Ageism, a study of ageism in Canada, found ageism to be prevalent and the most tolerated form of social prejudice in the country (Wellner \& Spadafora, 2016). The Report identified the need to: reframe aging and combat ageism, recognize one's own aging stereotypes and prejudices, educate people about aging and ageism, and foster intergenerational relationships and collaborations. It noted that positive attitudes about aging and knowledge about aging are essential to combating ageism. The Revera Age is More (http://ageismore.com) initiative addresses the need to combat the negative assumptions, attitudes, and stereotypes faced by older adults and celebrates the ageless spirit of older adults.

The FrameWorks Institute Report, Finding the Frame: An Empirical Approach to Reframing Aging and Ageism, addressed the need to: reframe perceptions of aging, increase public awareness of ageism, improve attitudes about aging, and combat ageism (Sweetland et al., 2017). Ageist attitudes tend to become self-fulfilling prophecies. People who expect a downward course of life tend to live life accordingly (McGuire, Klein, \& Couper, 2005). People cannot afford to face the future with a mindset of ageism and gerontophobia and society cannot afford to have its future guided by people who grow up ignorant about aging (Couper \& Pratt, 1999).

\section{Attitudes about Aging}

Attitudes about aging are a significant factor in how people age (Dychtwald \& Fowler, 1990). Ageist attitudes are propagated from one generation to the next and are transmitted through all the media by which societal knowledge, values, and attitudes are perpetuated. Even Facebook, a popular form of social media, has been identified as a site for ageist stereotypes (Levy, Chung, Bedford, \& Navrazhina, 2013). Unfortunately, research has consistently shown that even young children have ageist attitudes, and that these attitudes increase as the child grows older-this 
needs to change and a more positive view of aging needs to be enhanced.

Research has consistently shown that people who have positive attitudes and perceptions about aging are living longer, healthier lives than their counterparts who do not (Levy, 2009; Levy, 2003; Levy, 1996; Levy, Pilver, Chung, \& Slade, 2014; Levy, Pilver, \& Pietryzak, 2014; Levy, Slade, Chung, \& Gill, 2015; Levy, Slade, Kunkel, \& Kasl, 2002; Levy, Slade, Murphy, \& Gill, 2012; Levy, Zonderman, Slade, \& Ferrucci, 2012; Levy, Zonderman, Slade, \& Ferrucci, 2009). This research has additionally shown that negative age stereotypes and perceptions are predictors of adverse outcomes in old age, tend to become internalized across the lifespan, can operate unconsciously, gain self-relevance, have negative psychological, behavioral, and physiological impacts, and are a risk factor of cardiovascular disease. It has also shown that positive, nonageist attitudes can help to combat these adverse outcomes, that people with positive attitudes about aging have a lower incidence of psychiatric conditions, more resilience when encountering stressful events, better recovery from disabling events, better memory, better balance, and are living longer. An alarming research finding is that negative age stereotypes predict Alzheimer's disease biomarkers (Levy et al., 2016). Such findings emphasize the importance of combating ageism and promoting positive attitudes about aging. Lifespan aging education can help to promote knowledge about aging, promote positive attitudes about aging, combat ageism, avoid adverse outcomes in old age, promote aging with optimism, and aid the effort to reimage worldwide aging.

\section{Lifespan Aging Education}

In general, people reach later life with little or no formal education on aging or anticipatory guidance about aging. In the United States lifespan aging education has been endorsed since the first White House Conference on Aging, Education and Aging in 1961 (United States Department of Health, Education, \& Welfare, 1961). However, little is happening in the U.S. in homes, schools, and communities in relation to aging education (McGuire, Klein, \& Couper, 2005) and lack of this education is likely a worldwide phenomenon. Research has consistently shown that aging education can help to dispel ageist myths and stereotypes, and combat ageism and gerontophobia. This education should start with young children. "If we teach children that growing old is a natural part of life, and raise them to appreciate and value the contributions of older people to their world, ageist stereotypes and fears of growing old will become obsolete" (Butler, 1999, p. v).

Aging education should teach about the potential for good health, activity, productivity, and creativity at all stages of life (Pratt, 1987). It should be intergenerational, developmentally focused, anticipatory education that promotes positive attitudes about aging (McGuire, 1993). It includes cognitive knowledge but should also contribute to the affective domain of learning (McGuire et al., 2005). The devastating d's of death, dying, disease, disability, dementia, decline, and dependence are not synonymous with aging and should not be the focus of aging education (McGuire, 2016). When these topics are addressed it should be within a lifespan 
context since people can become ill, disabled, dependent and die at all ages.

The foundation for successful aging should begin during youth and be built on throughout life. The child's developmental level is important to consider with aging education. Preschool children and children in early grades can benefit from positive aging role models, answering questions about aging, and books with positive portrayals of older adults; older children grades can begin to explore scientific approaches to aging and the social implications of aging; middle school and older children can learn about older adults contributions to society and social implications and resources for living in an aging world (Generations United, 2017). Jantz, Seefeldt, Galper, \& Serock (1976) in their classic study of children's attitudes toward older adults stated three goals for aging education curricula with children: 1) to provide accurate information about older adults; 2) to enable children to assess their perceptions of the aging process and how it affects them; and 3) to expose children to an unbiased look at the attributes, behaviors, and characteristics of older adults in a variety of roles. Table 1 suggests a conceptual framework for lifespan aging education.

\section{Why Teach about Aging?}

People will learn about aging whether we teach them or not, but all too often what they learn about aging is based on myths about the aging process and stereotypes of people that are entrenched in our cultures (Pratt, 1992). Aging education can help to dispel this; is important for people of all ages; and enables addressing the omissions, stereotypes, and misleading information that often characterizes people's knowledge of aging (National Retired Teachers Association (NRTA) \& National Academy for Teaching and Learning about Aging (NATLA), 1998). It can give people an informed, balanced view of aging. Mr. Fran Pratt, the founder and Executive Director of both the Teaching and Learning about Aging project and the Center for Understanding Aging, was a champion of the aging education movement. Today, aging education needs such a champion. Fortunately many of the aging education documents produced under his leadership, and other aging education documents, remain available in the Education Resources Information Center (ERIC).

Table 1. Lifespan Aging Education: A Conceptual Framework.

Concept 1: Aging is a natural and lifelong process of growing and developing

Concept 2: Older people and younger people are similar in many ways

Concept 3: Older people are valuable and contributing members of society

Concept 4: Old and young can enjoy each other and learn from each other

Concept 5: People need to plan for becoming older

Concept 6: People have much control over the older person they become

Concept 7: Attitudes about aging play a significant role in how people age 


\section{Education Resources Information Center (ERIC)}

There is little mention of aging education at the precollege level until the 1960s (Myers, 1977; Myers, 1979; Ulin, 1982). In the 1970s and 1980s aging education began to command attention with resources such as the Teaching and Learning about Aging project and the Center for Understanding Aging. These and other resources championed aging education and produced many aging education resources that remain available in ERIC.

ERIC is sponsored by the Institute for Education Services (IES) in the U.S. Department of Education and is available for worldwide access at http://eric.ed.gov. The Center catalogs significant education resources including journal articles, monographs, and conference presentations. Once selected for inclusion the materials remain permanently available. Information on submitting to ERIC, and the review and selection process, is located on the website. Catalogued materials can be located through topical searches and by author name. Many materials are available free for full-text download. Journal articles catalogued in ERIC generally have to be obtained through the publishing journal.

Many aging education materials have become rather "fugitive" in nature and difficult to locate. Fortunately, the classic book Learning for Longer Life: A Guide for Developers of K-12 Curriculum and Instructional Materials (Couper \& Pratt, 1999), is available in ERIC. The book discusses why education for longer life is needed, content that should be included, how content on aging can be presented, resources for aging education, general learning objectives about aging, and sample classroom activities. However, it is important to remember that aging education should not be limited to classroom activities, but incorporated into everyday life. Table 2 is a compilation of number of full-text ERIC aging education materials. Selected intergenerational resources are included as they are effective interventions for education about aging. ERIC is a valuable resource for preserving education resources, and visiting the website and submitting documents for inclusion is encouraged.

Table 2. Education Resources Information Center (ERIC): Aging Education Materials. http://eric.ed.gov.

ERIC Documents: Full-Text Available

Angelis, J. (1990). Intergenerational service-learning. ED339005

Atwood, H. M. (1975). Activities for teaching about aging. Primary and secondary grades. Ball State University, Teacher's College. ED156552

Baranowski, M., \& Schilmoeller, G. (1981). School-based programs for facilitating positive attitudes toward the elderly. Paper presented at the Annual Meeting of the New England Educational Research Organization. ED206557

Betourney, W. (1981). Demographics of aging. Implications for the future. Acton, MA: Acton-Boxborough School District. ED211408 


\section{Continued}

Briggs, H.-S. (1987). Teaching aging. A series of training modules on aging for educators. University of South Florida, College of Applied and Behavioral Sciences, Human Resources Institute, Center for Applied Gerontology. ED295085

Connecticut Department of Education \& Connecticut Department on Aging. (1992). Schools In At Aging Society series:

- $\quad$ Strengthening the School Community Connection ED368057

- $\quad$ Elders as Resources ED405519

- $\quad$ A Guide for Pupil Personnel Specialists ED403499

- Social Studies Classroom Activities ED370875 (pending restoration)

- $\quad$ Language Arts Classroom Activities ED366959

- Health/Home Economics ED369775

Corrigan, T. McNamara, G., \& O'Hara, J. (2013). Intergenerational Learning. A Valuable Learning Experience for Higher Education. EJ1060383

Couper, D., \& Pratt, F. (1999). Learning for longer life. A guide for developers of K-12 curriculum and instructional materials. National Retired Teachers Association and National Academy for Teaching and Learning About Aging. ED477891

Dodson, A. E. \& Hause, J. B. (1981). Realistic portrayals of aging. Acton, MA: Acton-Boxborough School District, McCarthy-Towne School. Teaching and Learning About Aging project. ED211409 Dodson, A. E. \& Hause, J. B. (1981). Ageism in literature: An analysis kit for teachers and librarians.Acton, MA: Acton-Boxborough School District, McCarthy-Towne School. Teaching and Learning About Aging project. ED211410

Doyle, R. E., \& Pappas, A. A. (1982). Math activities for teaching about aging. Acton, MA: Ac ton-Boxborough School District, McCarthy-Towne School. Teaching and Learning About Aging project. ED213642

Edwards, A. J., \& Roubine, D. L. (1985). Developing an aging curriculum. ED258098

Frost, G. (1981). Confrontation: Aging in America. Acton, MA: Acton-Boxborough School District, McCarthy-Towne School. Teaching and Learning About Aging project. ED211407

Hatton-Yeo, A., \& Ohsako, T. (2000). Intergenerational programmes. Public policy and research implications $-A n$ international perspective. United Nations Educational, Scientific, and Cultural Organization. ED458364

Hittleman, C. G., \& Hittleman, D. R. (1996). Grandparents and grandchildren in children's literature: Interactions that enhance learning. Prague: Czech Republic: Paper presented at the World Congress on Reading. ED397391

Laney, J., Wimsatt, T. J., Moseley, P. A., \& Laney, J. L. (1997). Children's ideas about aging befor and after an integrated unit of instruction. Paper presented at the Annual Meeting of the Educationa Research Association. ED408109

Maryland Intergenerational Coalition (2002). How to start intergenerational programs in communi ties. ED473669

McGuire, S. L. (2016). Growing up and growing older. Books for young readers. An annotated booklist of literature to promote positive aging (Preschool-third grade). ED570955

[Earlier versions of the booklist are ED292088 (1987), ED347515 (1992), \& ED445344 (2000)]

McGuire, S. L. (2016). Early children's literature and aging. Creative Education, 7, 2604-2612 ED570959 


\section{Continued}

McGuire, S. L. (1988). Health and aging curriculum. Grade level: Preschool-third grade. ED291738

Newman, S. (1993). Creating Effective Intergenerational Programs. ED448078

Newman, S. (1995). History and Current Status of the Intergenerational Field. ED448079

Newman, S. (1997). Rationale for Linking the Generations. ED448080

New York Rural Education Advisory Committee. (1999). Welcome to Generations Together. Reading for the Future. An Intergenerational Program for Schools. ED445846

Paranya, A. C. (1974). Unit on Aging. ED098125

Peters, E. (1981). Teaching and learning about aging. Evaluation report. Acton, MA: Acton-Boxborough School District. Teaching and Learning About Aging. ED211410

Pratt, F. (1976). Teaching about aging. Boulder, CO: Social Science Education Consortium (Publication \#197). ED135682 (Pending Restoration)

Pratt, F. (1981). What's it all about? Acton, MA: Acton-Boxborough School District. Teaching and Learning About Aging project. ED211405

Pratt, F. (1981). Education for aging. A teacher's sourcebook. Acton, MA: Acton-Boxborough School District. Teaching and Learning About Aging project. ED211406

Surlis, M. (2012). A Window of Wonder. An Insight Into Intergenerational Learning in the Irish Second-Level Education System. EJ991815

Ulin, R. O. (1982). Teaching and learning about aging. Washington, DC: National Education Association. ED228581

Valeri-Gold, N. (1985). Bridging the generations: Helping students understand the elderly (K-7).Choosing and using children's books. ED278046

Werst, D. (1982). What's it like to be old? Acton, MA: Acton-Boxborough School District. ED214818

Woodward, K. A. (1993). Elementary school-based adopted grandparent programs. Combining intergenerational programming with aging education. Paper presented at the Annual Meeting of the Association for Gerontology in Higher Education. ED361113

\section{Children's Literature and Aging Education}

Ageism has crept its way into children's literature (Ansello, 1988; Ansello, 1977; McGuire, 2005). However, when carefully selected, children's literature has been shown to be an important aging education resource (Crawford, 2000; McGuire, 2016). Books with positive aging content need to be part of home, school, and community libraries (McGuire, Senter, \& Stevens, 2013). They can stimulate interesting discussions about aging, help children learn about growing up and growing older, and start planning for the long life ahead of them. Ageist attitudes start early, and the following resources focus on early children's literature (Preschool-Primary) in an effort to begin promoting positive attitudes about aging that can be built on across the lifespan.

The Growing Up an Growing Older. Books for Young Readers annotated 
booklist focuses on literature for young children (Preschool-Primary) that can assist in laying a foundation for positive aging and combat ageism (McGuire, 2017). It contains a list of favorite books-in-print, annotated bibliographies of favorite books-in-print and favorite out-of-print books, and multicultural and topical listings. It can be accessed free, online at

http://library.lmunet.edu/booklist. Booklist books help children to see their "elder within"-the older person they can become (Dychtwald \& Fowler, 1990), see the potentials of aging, and think in terms of "lifespan activities"-activities they can do now and can do as an older person.

$A$ is for Aging, B Books website is hosted by Lindsey McDivitt, a children's book author, and is available at: http://www.lindseymcdivitt.com. It is an excellent resource for locating children's literature with nonageist content (McGuire, 2016). The books on the website avoid negative stereotypes in texts and illustrations and "stay away from narrow portrayals of older adults and acknowledge the variety of interests, abilities, and talents that do not melt away with old age, but grow with experience" (McDivitt, 2015). The website has informative links, presents reasons why it is important to promote positive attitudes about aging, and notes that children's literature can be used to combat ageism.

Since 2009, the Association for Gerontology in Higher Education (AGHE) has had a book award for Best Children's Literature on Aging. The award recognizes books that recognize positive, meaningful portrayals of older adults (AGHE, 2017). It strives to heighten awareness of authors and publishers on how older adults are portrayed in this literature. A reading list of selected children's books on aging is available at the AGHE website under "Publications". The award is an important resource for combating ageism and promoting positive portrayals of older adults, but unfortunately is not well known (Simeon, 2016).

\section{Intergenerational Connections as Aging Education}

Intergenerational collaborations can educate about aging, promote understanding between generations, and combat ageism (Sweetland et al., 2017; Friedman, 1999; McDuffie \& Whiteman, 1989; Newman, 1997; Newman, 1993; Wellner \& Spadafora, 2016). Some of the most successful learning environments are those where children and seniors learn together (Morgan \& Ellis, 2007). Limitless opportunities exist for these collaborations in communities worldwide but are often underutilized. Every day presents opportunities to connect generations, but taking the initiative is the key. These everyday examples include things such as older adults in schools and child care centers, children assisting older adults, intergenerational service learning, intergenerational choirs, intergenerational orchestras and music programs, intergenerational art activities, and intergenerational environmental and community projects. Intergenerational community centers effectively incorporate older people into communities and combat ageism (Sweetland et al., 2017). Intergenerational connections can happen imme- 
diately, at little or no cost, and with proven reciprocal rewards (Wellner \& Spadafora, 2016).

Dr. Sally Newman, a champion of intergenerational scholarship and practice and founder of Generations Together at the University of Pittsburgh and the Journal of Intergenerational Relationships, noted that increased age segregation has resulted in decreased intergenerational exchange, knowledge, and understanding (Newman, 1995; Newman, 1997). Her works in the intergenerational field are classics including her book, Intergenerational Programs. Past, Present, and Future (Newman, Ward, Smith, Wilson, \& McCrea, 1997). The book is out-of-print but often available through libraries and vendors.

The Education Resources Information Center [ERIC] (http://eric.ed.gov) has numerous intergenerational resources available and some of these are highlighted in Table 2. Generations United (http://www.gu.org) is an international organization that strives to improve the lives of children, youth, and older adults through intergenerational collaboration, public policies, and programs. The organization promotes knowledge and understanding between generations, offers numerous resources, and holds yearly international conferences. The Association for Gerontology in Higher Education has an Intergenerational Learning, Research and Community Engagement committee (http://www.aghe.org). The Washington, DC Center on Aging (http://dccenteronaging.org) sponsors innovative programs that focus on intergenerational communication and older people as a national resource. The Center's Societal Education about Aging For Change (SEAChange) initiative has suggestions for children's intergenerational media to promote positive aging. Other intergenerational resources include Penn State University's Intergenerational Program

(http://www.aese.psu.edu/extension/intergenerational) and its Generations Activities Sourcebook (Penn State, 2003) publication and Temple University's Intergenerational Center (http://education.temple.edu/igc). Intergeneration Month (http://www.intergenerationmonth.org) began in 2000 as "Intergeneration Day" and in 2012 Intergeneration Month was launched and is an international opportunity to bring generations together and promote aging education.

\section{Other Aging Education Resources}

\subsection{Positively Aging®}

Positively Aging ${ }^{\oplus}$ began as an innovative set of interdisciplinary teaching materials that used examples from geriatrics and gerontology to teach middle school health and science and includes content that illustrates how lifestyle practices impact on life's later years. Research demonstrated the materials promoted more positive attitudes about age and aging with middle school students (Lichtenstein et al., 2005; Lichtenstein et al., 2001). Curriculum units incorporate health and aging across the lifespan and topics include: My Older Friend, Give Your Bones a Break, Embracing Diversity, Discrepant Design: Levers in the Body, Mobility. Movement by the Numbers, Nutrition and Aging, and Our Aging World. The 
It's All in Your Mind unit covers brain health, memory, and dementia. The curriculum is incorporated into the Teacher Enrichment Initiatives (TEI) partnership with the University of Texas Health Science Center in San Antonio, Texas. Curricular materials are available free at http://teachhealthk-12.uthscsa.edu.

\subsection{The Association for Gerontology in Higher Education (AGHE)}

AGHE's annotated bibliography, Teaching about Aging for Children and Youth, provides resources for teaching about aging (McGuire \& Tompkins, 2004). AGHE also has a K-12 Gerontology Education committee. The committee sponsors the AGHE award for Best Children's Literature on Aging. Its mission includes facilitating inclusion of aging content into K-12 school curricula at local, state, national, and international levels and developing a network of professionals interested in teaching children about aging.

\subsection{Self-Awareness}

The importance of self-awareness in relation to attitudes about aging was incorporated in both the FrameWorks Institute Report, Finding the Frame: An Empirical Approach to Reframing Aging and Ageism, (Sweetland et al., 2016) and the Revera Report on Ageism (Wellner \& Spadafora, 2016). Evaluating one's own attitudes about aging is an aging education and ageism awareness intervention. It is important to understand one's attitudes about aging, how these attitudes may be perceived by others, and how they may impact others (Wellner \& Spadafora, 2016). In self-evaluation ageist attitudes may become evident. This can inspire self-learning about aging, efforts to combat ageist attitudes, becoming an advocate for combating ageism, promoting positive aging, and viewing aging with optimism. It can help people to explore their "elder within" (Dychtwald \& Fowler, 1990), what they would like to be as an older adult, and what they need to do to accomplish it.

\subsection{Internet and Media Resources}

Internet and media resources can provide useful information on aging. However, they need to be reputable and carefully screened for how factual the information is. Reputable websites with information on aging can be effective educational sites. Worldwide, countries will have organizations and resources that have information on aging and older adults that can be explored. As an example, in the United States, it would be beneficial for older students and adults to explore internet sites including Social Security, Medicare, Medicaid, Eldercare Locator, Meals on Wheels, National Institute on Aging, Center for Community Living, state Agencies on Aging, Area Agencies on Aging, Senior Centers, Road Scholar (formerly Elderhostel), Benefits Check Up, and Gray Panthers, Environmental Protection Agency Aging Initiative, Gerontological Society of America, and American Society on Aging. Worldwide, organizations and resources have informative information on aging and can be explored. 
Popular videos can be screened for aging content. A video, Age of Champions, (http://ageofchampions.org) is an award winning documentary of Senior Olympic athletes that includes a 100 year old tennis player, an 86 year old pole vaulter and events such as women's basketball and track and field. This actual footage of Senior Olympic games and is excellent viewing for young and old alike. Terra Nova Films (http://www.terranova.org) distributes films and videos dealing exclusively with aging and elderhood that help to understand and navigate life's later years. Terra Nova has intergenerational films such as: Still Dreaming, Flowers for Charlie, Cyber-Seniors, and Surrounded with Love: Grandparents Raising Grandchildren. Other Terra Nova films include: Spirit of Senior Softball, Surfing for Life, and Louise.

\section{Conclusion}

Aging is a lifelong experience in which everyone is already involved. Increased life expectancy worldwide makes preparation for a long life in an aging world imminently important. People need to maximize the longevity dividend they have been given and view "aging with optimism". This article has focused on the need for aging education to help prepare people for the long life ahead and living in an aging world, the need to combat ageism, and presented resources for achieving both. These efforts will involve worldwide initiatives. A number of the aging education resources presented involved laying a foundation for positive aging with children. Today's children are the future of tomorrow. They will be leaders, teachers, policy makers, and older adults of tomorrow. Let's strive to give them the gifts of successful aging, quality of life in old age, and the readiness to live life in an aging world.

Many aging education opportunities can be implemented immediately, at little cost, and with proven outcomes. Aging education needs champions! Combating agism needs champions! Opportunities to be champions exist everyday in our homes, schools, communities. Be a champion for improving the quality of life in old age for everyone, everywhere! We can all be these champions. Let's do it!!

\section{References}

Ansello, E. F. (1977). Age and Ageism in Children's First Literature. Educational Gerontology, 2, 255-274. https://doi.org/10.1080/0360127770020305

Ansello, E. F. (1988). Early Socialization to Biases through Children's Literature. Presentation at the $34^{\text {th }}$ Annual Meeting of the American Society on Aging, San Diego, CA.

Association for Gerontology in Higher Education (2017). Book Award for Best Children's Literature on Aging.

http://www.aghe.org/membership/awards/book-award-for-best-children-s-literature-o n-aging

Butler, R. (1969). Age-Ism: Another form of Bigotry. Gerontologist, 9, 243-246.

https://doi.org/10.1093/geront/9.4_Part_1.243

Butler, R. (1995). Ageism. In G. Maddox (Ed.), The Encyclopedia of Aging (2nd ed., pp. 
38-39). New York: Springer Publishing.

Butler, R. (1999). Foreword. In D. Couper, \& F. Pratt, Learning for a Longer Life. Aguide for Developers of K-12 Curriculum and Instruction Materials (p. v). Denton, TX: National Academy for Teaching and Learning about Aging (NATLA).

Butler, R., \& Lewis, M. I. (1973). Aging and Mental Health. St. Louis, MO: C. V. Mosby.

Couper, D., \& Pratt, F. (1999). Learning for a Longer Life. A Guide for Developers of K-12 Curriculum and Instruction Materials. Denton, TX: National Academy for Teaching and Learning about Aging (NATLA).

Crawford, P. A. (2000). Crossing Boundaries: Addressing Ageism through Children's Books. Reading Horizons, 40, 161-174.

Crawford, P. A. (2015). Rock of Ages: Developing Healthy Perspectives of Aging in the Elementary Grades. Childhood Education, 91, 395-401. https://doi.org/10.1080/00094056.2015.1090858

Dychtwald, K., \& Fowler, J. (1990). Age Wave. New York, NY: Bantam Books.

Friedman, B. M. (1999). Integrating Aging Education and Intergenerational Programs with Elementary and Middle Grade Curricula. Needham, MA: Allyn \& Bacon.

Generations United (2017). Intergenerational Learning Activities: Aging. http://www.gu.org/RESOURCES/LearningActivities/IntergenerationalLearningActiviti esAging.aspx

Jantz, R. K., Seefeldt, C., Galper, A., \& Serock, K. (1976). Children's Attitudes toward the Elderly. Final Report to the American Association of Retired Teachers and National Retired Teachers Association. College Park, MD: University of Maryland-Center on Aging and Department of Early Childhood/Elementary Education.

Levy, B. (1996). Improving Memory in Old Age through Implicit Self-Stereotyping. Journal of Personality and Social Psychology, 71, 1092-1107. https://doi.org/10.1037/0022-3514.71.6.1092

Levy, B. (2003). Mind Matters: Cognitive and Physical Effects of Aging Self-Stereotypes. Journal of Gerontology, 58B, 203-211. https://doi.org/10.1093/geronb/58.4.P203

Levy, B. (2009). Stereotype Embodiment: A Psychosocial Approach to Aging. Current Directions in Psychological Science, 18, 332-336. https://doi.org/10.1111/j.1467-8721.2009.01662.x

Levy, B. R., Chung, P. H., Bedford, T., \& Navrazhina, K. (2013). Facebook as a Site for Negative Age Stereotypes. Gerontologist, 54, 172-176.

https://doi.org/10.1093/geront/gns194

Levy, B. R., Ferrucci, L., Zonderman A., Slade, M. D., Troncoso, J., \& Resnick, S. M. (2016). A Culture-Brain Link: Negative Age Stereotypes Predict Alzheimer's Disease Biomarkers. Psychology and Aging, 31, 82-88. https://doi.org/10.1037/pag0000062

Levy, B. R., Pilver, C. E., \& Pietrzak, R. H. (2014). Lower Prevalence of Psychiatric Conditions when Negative Age Stereotypes Are Resisted. Social Science and Medicine, 119, 170-174.

Levy, B. R., Pilver, C., Chung, P., \& Slade, M. D. (2014). Subliminal Strengthening Improving Older Individuals Physical Function over Time with an Implicit-Age-Stereotype Intervention. Psychological Science, 25, 2127-2135.

https://doi.org/10.1177/0956797614551970

Levy, B. R., Slade, M. D., Chung, P. H., \& Gill, T. M. (2015). Resiliency over Time of Elders' Age Stereotypes after Encountering Stressful Events. Journals of Gerontology Series 
B: Psychological Sciences and Social Sciences, 70, 886-890.

https://doi.org/10.1093/geronb/gbu082

Levy, B. R., Slade, M. D., Kunkel, S., \& Kasl, S. (2002). Longevity Increase by Positive Self-Perception of Aging. Journal of Personality and Social Psychology, 83, 261-270. https://doi.org/10.1037/0022-3514.83.2.261

Levy, B. R., Slade, M. D., Murphy, T. E., \& Gill, T. M. (2012). Association between Positive Age Stereotypes and Recovery from Disability in Older Persons. Journal of the American Medical Association, 308, 1972-1973.

https://doi.org/10.1001/jama.2012.14541

Levy, B. R., Zonderman, A. B., Slade, M. D., \& Ferrucci, L. (2009). Age Stereotypes Held Earlier in Life Predict Cardiovascular Events in Later Life. Psychological Science, 67, 432-436. https://doi.org/10.1111/j.1467-9280.2009.02298.x

Levy, B. R., Zonderman, A. B., Slade, M. D., \& Ferrucci, L. (2012). Memory Shaped by Age Stereotypes over Time. Journal of Gerontology: Psychological Science, 20, 296-298. https://doi.org/10.1093/geronb/gbr120

Lichtenstein, M. J., Pruski, L. A., Marshall, C. E., Blalock, C. L., Lee, S., Murphy, D. L., Plaetke, R., \& Lee, S. (2001). The Positively Aging Teaching Materials Improve Middle School Students' Images of Older People. The Gerontologist, 41, 322-332.

https://doi.org/10.1093/geront/41.3.322

Lichtenstein, M., Pruski, L., Marshall, C., Blalock, C., Lui, Y., \& Plaetke, R. (2005). Disseminating the Positively Aging Teaching Materials: Results of a Controlled Study. Educational Gerontology, 31, 541-561. https://doi.org/10.1080/03601270590962505

McDivitt, L. (2015). A Is for Aging, B is for Books. http://www.lindseymcdivitt.com

McDuffie, W., \& Whiteman, J. R. (1989). Intergenerational Activities Program Handbook (3rd ed.). Bingham, NY: Broome County Child Development Council, Inc. International Activities Council. Funded by the Gannett Foundation.

McGuire, S. L. (1993). Promoting Positive Attitudes about Aging through Aging Education: A Study with Preschool Children. Gerontology and Geriatrics Education, 13, 3-12. https://doi.org/10.1300/J021v13n04_02

McGuire, S. L. (2005). Children's Literature. In: E. B. Palmore, L. Branch, \& D. K. Harris (Eds.), Encyclopedia of Ageism (pp. 68-71). Binghamton, NY: Haworth Press.

McGuire, S. L. (2016). Early Children's Literature and Aging. Creative Education, 7, 2604-2612. https://doi.org/10.4236/ce.2016.717245

McGuire, S. L. (2017). Growing up and Growing Older. Books for Young Readers. Harrogate, TN: Lincoln Memorial University. http://library.lmunet.edu/booklist

McGuire, S. L., \& Tompkins, C. (2004). Teaching about Aging for Children and Youth. Washington DC: Association for Gerontology in Higher Education. Annotated Bibliography Series.

McGuire, S. L., Klein, D., \& Couper, D. (2005). Aging Education: A National Imperative. Educational Gerontology, 31, 443-460. https://doi.org/10.1080/03601270590928170

McGuire, S. L., Senter, S., \& Stephens, B. (2013). Growing up and Growing Older. Promotion of Nonageist Literature for Children. In Tennessee Library Association 2013 Conference: "Libraries Out of the Box".

Morgan, R. E., \& Ellis, D. W. (2007). The Longevity Revolution: New Opportunities for Science Centers. Public Policy and Aging Report, 17, 1-6.

https://doi.org/10.1093/ppar/17.1.1

Myers, J. W. (1977). Aging Curricula for the Public Schools. Objectives and Materials. 
Unpublished Doctoral Dissertation, Akron, OH: University of Akron.

Myers, J. W. (1979). Aging Education for the Junior High-Middle School Years. Education Resources Information Center [ERIC] ED204251.

National Retired Teachers (NRTA) \& National Academy for Teaching and Learning about Aging (NATLA) (1998). Teaching about Aging. Enriching Lives across the Lifespan. Washington DC: NRTA.

Newman, S. (1993). Creating Effective Intergenerational Programs. Educational Resources Information Center [ERIC] ED448078.

Newman, S. (1995). History and Current Status of the Intergenerational Field. Educational Resources Information Center [ERIC] ED448079.

Newman, S. (1997). Rationale for Linking the Generations. Educational Resources Information Center [ERIC] ED448080.

Newman, S., Ward, C. R., Smith, T.B., Wilson, J. O., \& McCrea, J. M. (1997). Intergenerational Programs. Past, Present, and Future. New York, NY: Routledge.

Palmore, E. B. (2001). The Ageism Survey: First Findings. The Gerontologist, 41, 572-575. https://doi.org/10.1093/geront/41.5.572

Palmore, E. B. (2003). Combating Ageism. Symposium Presentation, Knoxville, TN: The University of Tennessee.

Palmore, E. B. (2004). Research Note: Ageism in Canada and the United States. Journal of Cross Cultural Gerontology, 19, 41-46. https://doi.org/10.1023/B:JCCG.0000015098.62691.ab

Palmore, E. B., Branch, L., \& Harris, D. K. (2005). Encyclopedia of Ageism. Binghamton, NY: Haworth Press.

Penn State University Intergenerational Program (2003). Intergenerational Activities Sourcebook.

Pratt, F. (1983). Why Teach about Aging? Southington, CT: Center for Understanding Aging.

Pratt, F. (1987). Teaching Today's Kids-Tomorrow's Elders. In H. Cox (Ed.), Aging (5th ed., pp. 93-99). Guildford, CT: Duskin Publishing.

Pratt, F. (1992). Why Teach about Aging? In D. Couper, \& D. W. Gregg (Eds.), Schools in an Aging Society. Social Studies Classroom Activities for Secondary Schools (pp. 101-102). Hartford, CT: Connecticut Department of Education and Connecticut Department of Aging. Educational Resources Information Center (ERIC) ED370875.

Simeon, L. R. (2016). Diversity 102: Ageism in Children's Literature.

Sweetland, J., Volmert, A. E., \& O’Neil, M. (2017). Finding the Frame: An Empirical Approach to Reframing Aging and Ageism. Washington DC: FrameWorks Institute.

Ulin, R. O. (1982). Teaching and Learning about Aging. Washington DC: National Education Association.

United Nations (2015). World Population Ageing 2015: Highlights. New York, NY: Author.

United States Department of Health, Education and Welfare (1961). White House Conference on Aging. Education and Aging. Washington DC: Author.

Wellner, T., \& Spadafora, P. (2016). Revera Report on Ageism: Independence and Choice as We Age. Ontario: Revera, Inc. 
Submit or recommend next manuscript to SCIRP and we will provide best service for you:

Accepting pre-submission inquiries through Email, Facebook, LinkedIn, Twitter, etc. A wide selection of journals (inclusive of 9 subjects, more than 200 journals)

Providing 24-hour high-quality service

User-friendly online submission system

Fair and swift peer-review system

Efficient typesetting and proofreading procedure

Display of the result of downloads and visits, as well as the number of cited articles Maximum dissemination of your research work

Submit your manuscript at: http://papersubmission.scirp.org/

Or contact ce@scirp.org 